\title{
KOMPRESI CITRA DENGAN MENGGUNAKAN METODE DELTA MODULATION
}

\author{
Didik Ardiyanto, Bambang Hari Purwoto \\ Jurusan Teknik Elektro Fakultas Teknik Universitas Muhammadiyah Surakarta \\ J1. A. Yani Tromol Pos 1 Pabelan Kartasura 57102 Telp 0271717417 \\ Email: d400080037@students.ums.ac.id
}

\begin{abstract}
ABSTRAKSI
Kompresi citra merupakan suatu teknik yang digunakan untuk mengurangi biaya penyimpanan dan transmisi. Pemampatan atau kompresi citra merupakan suatu metode yang sangat bermanfaat bagi perkembangan citra digital. Dengan kompresi, data citra digital yang ukurannya besar, dapat dikompres sehingga mempunyai ukuran yang lebih kecil.Program kompresi citra dengan metode delta modulation ini, dibuat dengan GUI dan source coding. Dengan menerapkan fungsi dari Dmsig untuk pengolahan sinyal,maka didapatkan rumus untuk mengkompres gambar yang dipengaruhi oleh step size dan ukuran gambar tersebut.Kelebihan dari teknik Delta Modulation adalah dapat mengkompres gambar grayscale, black and white dan true color. Hasil gambar yang sudah dikompres menunjukkan bahwa metode ini baik untuk menghasilkan gambar dengan output berformat jpg,png dan tiff. Kualitas gambar yang paling baik dari hasil kompresi delta modulation yaitu gambar berformat jpg.Untuk tingkat kompresi yang paling bagus juga ada pada gambar berformat jpg,ini diambil berdasarkan nilai MSE dan PSNR yang di hitung pada gambar hasil kompresi.Tingkat kompresi dengan delta modulation termasuk tinggi karena masuk ke lossy compression.
\end{abstract}

Kata kunci: Kompresi citra, Delta Modulation, dan Kualitas gambar.

\section{PENDAHULUAN}

Pada saat ini, perkembangan dalam dunia teknologi berkembang sangat pesat. Hal ini ditandai dengan banyaknya produk-produk teknologi yang canggih yang beredar di pasaran. Begitu juga dalam dunia telekomunikasi. Kemajuan teknologi telekomunikasi saat ini juga telah berkembang dengan sangat pesat sehingga kebutuhan akan pendukung-pendukung di dalamnya menjadi tidak terelakkan.

Perkembangan perangkat bergerak seperti handphone, PDA dan notebook tentu juga diiringi dengan perkembangan perangkat lunak untuk dapat menjalankan berbagai aplikasi seperti mengetik dokumen, melihat foto, memainkan musik, melihat video dan banyak hal lain yang tidak pernah dapat dibayangkan dalam beberapa dasawarsa yang lalu. Perangkat lunak sendiri juga mengalami perkembangan yang sangat signifikan dalam beberapa tahun terakhir dengan munculnya platform untuk mobile device seperti Symbian, Java dan Android.

Sistem komunikasi, data/informasi tidak hanya disajikan dalam bentuk teks, tetapi juga dapat berbentuk gambar, audio, dan video. Keempat macam data/informasi ini sering disebut sebagai multimedia. Era teknologi informasi saat ini tidak dapat dipisahkan dari multimedia. Situs web di internet dibuat semenarik mungkin dengan menyertakan visualisasi berupa gambar/video yang dapat diputar. Beberapa waktu lalu istilah sms (short message service) begitu popular bagi pengguna telepon genggam (handphone). Tetapi saat ini, orang dapat mengirim pesan tidak hanya dalam bentuk teks tetapi juga dapat mengirim pesan berupa gambar atau video yang dikenal dengan layanan MMS (Multimedia Message Service).

Citra (image) sebagai salah satu komponen multimedia memegang satu peranan sangat penting sebagai bentuk informasi visual. Citra memiliki karakteristik yang tidak dimiliki oleh data teks, yaitu citra kaya dengan informasi. Ada sebuah peribahasa yang berbunyi, " a picture is more than a thousand words " yang mempunyai makna : sebuah gambar lebih bermakna dari seribu kata, yang maksudnya sebuah gambar dapat memberikan informasi yang lebih banyak daripada informasi tersebut disajikan dalam bentuk kata-kata (tekstual).

Pada saat ini terjadi peningkatan yang cukup pesat terhadap permintaan kebutuhan 
komunikasi data, baik dari segi layanan, kehandalan sistem, maupun laju transmisinya. Data atau informasi tidak hanya disajikan dalam bentuk teks, tetapi juga dapat berbentuk gambar atau yang sering disebut dengan sebagai multimedia. Dengan berintegrasinya teknologi wireless dan layanan multimedia, pentransmisian citra dengan kualitas yang baik, merupakan hal yang sangat penting. Misalkan Situs web di internet dibuat semenarik mungkin dengan menyertakan visualisasi berupa gambar yang dapat ditampilkan dan dilihat, tetapi terkadang waktu untuk mengaksesnya di perlukan waktu cukup lama. Hal itu dikarenakan sinyal multimedia, yang memiliki ukuran data yang besar dan keterbatasan bandwidth.

\subsection{Pengertian Kompresi Image (Image Compressions)}

Kompresi Citra adalah proses untuk meminimalisasi jumlah bit yang merepresentasikan suatu citra sehingga ukuran data citra menjadi lebih kecil. Namun, seringkali kualitas gambar yang diperoleh jauh lebih buruk dari aslinya karena keinginan untuk memperoleh rasio kompresi yang tinggi. Pada dasarnya teknik kompresi citra digunakan pada proses transmisi data (data transmission) dan penyimpanan data (data storage). Kompresi citra banyak diaplikasikan dalam penyiaran televisi, penginderaan jarak jauh (remote sensing), komunikasi militer, radar, telekonferensi, pencitraan kedokteran, dan lain - lain.

Semakin besar ukuran citra, semakin besar memori yang dibutuhkan, namun kebanyakan citra mengandung duplikasi data, yaitu:

a. Suatu piksel memiliki intensitas yang sama dengan piksel tetangganya, sehingga penyimpanan piksel membutuhkan memori (space) yang lebih besar sehingga sangat memboroskan tempat.

b. Citra banyak mengandung bagian (region) yang sama sehingga bagian yang sama ini tidak perlu dikodekan berulang kali karena mubazir atau redundan.

Contohnya: citra langit biru dengan beberapa awan putih yang memiliki banyak intensitas dan region yang sama.
Manfaat kompresi citra adalah:

a. Waktu pengiriman data pada saluran komunikasi data lebih singkat.

Contoh: pengiriman gambar dari fax, videoconferencing, handphone, download dari internet, pengiriman data medis, pengiriman dari satelit, dan sebagainya.

b. Membutuhkan ruang memori dalam storage lebih sedikit dari pada representasi citra yang tidak dikompresi.

Kompresi citra merupakan suatu teknik yang digunakan untuk mengurangi biaya penyimpanan dan transmisi. Teknik-teknik yang ada yang digunakan untuk mengompresi file gambar secara luas. aplikasi kompresi data yang dilakukan terhadap citra digital dengan tujuan untuk mengurangi redudansi dari datadata yang terdapat dalam citra sehingga dapat disimpan atau ditransmisikan secara efisien.

Ada dua tipe utama kompresi data, yaitu kompresi tipe lossless dan kompresi tipe lossy. Kompresi tipe lossy adalah kompresi dimana terdapat data yang hilang selama proses kompresi. Akibatnya kualitas data yang dihasilkan jauh lebih rendah daripada kualitas data asli. Lossy compression menyebabkan adanya perubahan data dibandingkan sebelum dilakukan proses kompresi. Sebagai gantinya lossy compression memberikan derajat kompresi lebih tinggi. Tipe ini cocok untuk kompresi file suara digital dan gambar digital. File gambar secara alamiah masih bisa digunakan walaupun tidak berada pada kondisi yang sama sebelum dilakukan kompresi.

Sementara itu, kompresi tipe lossless tidak menghilangkan informasi setelah proses kompresi terjadi, akibatnya kualitas citra hasil kompresi juga tidak berkurang. Lossless Compression memiliki derajat kompresi yang lebih rendah tetapi dengan akurasi data yang terjaga antara sebelum dan sesudah proses kompresi. Kompresi ini cocok untuk basis data, dokumen atau spreadsheet. Pada lossless compression ini tidak diijinkan ada bit yang hilang dari data pada proses kompresi.

Teknik-teknik pengolahan citra mentransformasikan citra menjadi citra lain. Jadi, masukannya adalah citra dan keluarannya juga citra, namun citra keluaran mempunyai kualitas lebih baik daripada citra masukan. 
Termasuk ke dalam bidang ini juga adalah pemampatan citra (image compression).

Pemampatan atau kompresi citra merupakan suatu metode yang sangat bermanfaat bagi perkembangan citra digital. Dengan kompresi, data citra digital yang ukurannya besar, dapat dikompres sehingga mempunyai ukuran yang lebih kecil. Hal ini jelas sangat menguntungkan untuk berbagai aplikasi pertukaran data misalnya rekaman medis kedokteran (medical images) antar rumah sakit, rekaman kejahatan kepolisian (crime images) untuk data sidik jari (finger print).

Salah satu teknik kompresi yang cukup terkenal adalah kompresi JPEG (Join Photographic Expert Group). Kompresi JPEG menggunakan metode Lossless Compression, yaitu Kompresi citra dimana hasil dekompresi dari citra yang terkompresi sama dengan citra aslinya, tidak ada informasi yang hilang. Sayangnya ratio kompresi citra metode ini sangat rendah. Metode ini cocok untuk kompresi citra yang mengandung informasi penting yang tidak boleh rusak akibat kompresi, misal kompresi citra hasil diagnosa medis. Perhatikan contoh pemampatan citra dengan metode JPEG berikut ini.

Ada beberapa hal yang mesti di perhatikan saat melakukan kompresi gambar, yaitu:

a. Resolusi. Resolusi merupakan ukuran panjang kali lebar dalam suatu gambar yang digambarkan dalam satuan pixel.

b. Kedalaman bit. Kedalaman bit merupakan banyak sedikitnya jumlah bit yang dibutuhkan untuk menggambarkan suatu citra (gambar) dalam satuan bit/pixel. Tentu saja bila dinalar, semakin banyak bit maka gambar yang dihasilkan akan lebih bagus.

c. Redundansi. Redundansi adalah keadaan di mana representasi suatu elemen data tidak bernilai signifikan dalam menggambarkan keseluruhan data.

1.2 Pengertian Resolusi

Resolusi mengacu pada kerapatan pixel dalam sebuah gambar. Resolusi gambar diukur berdasarkan kerapatan pixel dalam 1 inch (pixels per inch / ppi atau dots per inch / dpi). Resolusi 1 ppi berarti ada satu pixel per 1 inch persegi. Begitu pula, resolusi 300 ppi brarti ada 300 pixel per satu inch persegi. Semakin besar resolusi, berarti semakin banyak pixel dalam sebuah gambar. Semakin besar resolusi gambar, semakin baik kualitasnya. Semakin besar resolusi, tampilan detail gambar akan semakin tampak. Kamu pun kemudian tahu, kenapa file yang berisi gambar-gambar atau image dengan resolusi tinggi mempunyai ukuran yang besar juga, karena pixel yang terkandung di dalamnya juga semakin rapat dan banyak.

Resolusi sering digunakan sebagai jumlah pixel dalam pencitraan gambar digital, walaupun standard Amerika, Jepang, serta internasional jelas melarang penggunaan hal ini, setidaknya untuk bidang kamera digital. Sebuah gambar dengan tinggi sejumlah $\mathrm{N}$ pixel dan lebar $\mathrm{M}$ pixel, dapat memiliki resolusi garis yang kurang dari itu. Namun, jika jumlah pixel digunakan sebagai pengukur resolusi, metode yang digunakan adalah mengambil dua buah bilangan bulat yang menunjukkan berapa pixel tinggi gambar tersebut dan berapa pixel lebarnya, kemudian mengalikan angka ini, dan membaginya dengan satu juta untuk mendapatkan angka megapixel. Hubungan antara Resolusi Gambar dan Besarnya File adalah Besarnya resolusi gambar berdampak langsung pada ukuran file. Semakin bagus kualitas gambar, resolusinya semakin besar maka ukuran file akan semakin besar juga.

\subsection{Pengertian Teknik Lossy Compression}

Teknik Lossy kompresi (Lossy compression) adalah suatu metode untuk mengkompresi data dan men-dekompresinya, data yang diperoleh mungkin berbeda dari yang aslinya tetapi cukup dekat perbedaaanya. Lossy kompresi ini paling sering digunakan untuk kompres data multimedia (Audio, gambar diam). Sebaliknya, kompresi lossless diperlukan untuk data teks dan file, seperti catatan bank, artikel teks dll. Format kompresi lossy mengalami generation loss yaitu jika melakukan berulang kali kompresi dan dekompresi file akan menyebabkan kehilangan kualitas secara progresif. hal ini berbeda dengan kompresi data lossless. ketika pengguna yang menerima file terkompresi 
secara lossy (misalnya untuk mengurangi waktu download) file yang diambil dapat sedikit berbeda dari yang asli dilevel bit ketika tidak dapat dibedakan oleh mata dan telinga manusia untuk tujuan paling praktis. Metode ini menghasilkan ratio kompresi yang lebih besar daripada metode lossless. Misal terdapat image asli berukuran 12,249 bytes, kemudian dilakukan kompresi dengan JPEG kualitas 30 dan berukuran 1,869 bytes berarti image tersebut $85 \%$ lebih kecil dan ratio kompresi $15 \%$. Contoh metode lossy adalah metode CS\&Q (coarser sampling and/or quantization), JPEG, dan MPEG.

Ada dua skema dasar lossy kompresi (Lossy Compression ) :

a. Lossy transform coding, sampel suara atau gambar yang diambil, di potong kesegmen kecil, diubah menjadi ruang basis yang baru, dan kuantisasi. hasil nilai kuantisasi menjadi entropy coding.

b. Lossy predictive coding, sebelum dan/atau sesudahnya data di-decode digunakan untuk memprediksi sampel suara dan frame picture saat ini. kesalahan antara data prediksi dan data yang nyata, bersama-sama dengan informasi lain digunakan untuk mereproduksi prediksi, dan kemudian dikuantisasi dan kode. Dalam beberapa system kedua teknik digabungkan, dengan mengubah coding yang digunakan untuk mengkompresi kesalahan sinyal yang dihasilkan dari tahapan prediksi. Bentuk terkenal dari Lossy predictive coding adalah Delta Modulation .

1.4 Pengertian Source Coding

Source Code (atau disebut juga source) adalah kumpulan dari beberapa kode bahasa pemrograman tertentu yang membentuk sebuah deklarasi / perintah yang dapat dibaca oleh komputer dan untuk menjalankan source code tersebut membutuhkan sebuah penterjemah dalam hal ini adalah software tertentu seperti 'Visual Studio' untuk dieksekusi / dikompile. kumpulan pernyataan atau deklarasi bahasa pemrogramman komputer yang ditulis dan dapat di baca manusia. Source code memungkinkan programmer untuk berkomunikasi dengan komputer menggunakan beberapa perintah yang telah terdefinisi.Source Code merupakan sebuah program yang biasanya dibuat dalam satu atau lebih file teks, kadang-kadang disimpan dalam database yang disimpan sebagai prosedur dan dapat juga muncul sebagai potongan kode yang tercetak di buku atau media lainnya. Banyaknya koleksi file source code dapat diatur dalam direktori pohon, dalam hal ini mungkin juga dikenal sebagai Source Tree.

Source encoding adalah sebuah proses dimana mengubah data yang didapat dalam sebuah bahasa mesin yaitu data bit binary string. Sebaliknya source decoding adalah sebuah proses yang mana akan mengubah data dari urutan beberapa bit binary string menjadi bahasa yang diketahui oleh pembaca. Misalkan saja angka 8 dalam proses source encoding diubah menjadi 00001000, sebaliknya dalam source decoding data bit string 00001000 diubah menjadi angka 8 . Dalam proses ini data yang didapat yaitu data grey level (kode warna) yang berupa data dengan type double, sehingga diperlukan pengubahan data berbentuk integer terlebih dahulu untuk membuat data tidak terdapat nilai pecahan.Sebaliknya source decoding adalah sebuah proses yang mana akan mengubah data dari urutan beberapa bit binary string menjadi bahasa yang diketahui oleh pembaca. Misalkan saja angka 8 dalam proses source encoding diubah menjadi 00001000 , sebaliknya dalam source decoding data bit stream 00001000 diubah menjadi angka 8 . Dalam proses ini data yang didapat yaitu data gray level (kode warna) yang berupa data dengan type double, sehingga diperlukan pengubahan data berbentuk integer terlebih dahulu untuk membuat data tidak terdapat nilai pecahan.

Pseudocode adalah deskripsi dari algoritma pemrograman computer yang menggunakan struktur sederhana dari beberapa bahasa pemograman tetapi bahasa tersebut hanya ditujukan agar dapat dibaca manusia. Biasanya yang ditulis dari pseudocode adalah variabel dan fungsi. Tujuan penggunaan utama dari pseudocode adalah untuk memudahkan manusia dalam memahami prinsip-prinsip dari suatu algoritma. Penggunaan pseudocode umumnya banyak kita temukan di buku-buku 
dan artikel-artikel tentang pemrograman yang membahas tentang algoritma tertentu. Kadang pula pseudocode kita temukan dalam merencanakan pengembangan suatu program komputer. Dalam pseudocode, tidak ada syntax standar yang resmi. Karena itu, pseudocode ini dapat kita terapkan dalam berbagai bahasa pemograman. Tentu saja harus kita sesuaikan setiap tahap dengan bahasa pemograman yang kita gunakan. Fungsi dari pseudocode mungkin sama dengan Flowchart. Perbedaannya terletak pada cara penyampaiannya. Pseudocode menggunakan kata-kata untuk menjelaskan suatu algoritma, sedangkan Flowchart menggunakan gambar.Salah satu teknik kompresi yang terkenal adalah kompresi JPEG (Join Photographic Expert Group),berikut adalah contoh source codingnya :

Function varargout $=$ aplikasi(varargin) gui_Singleton $=1$; gui_State $=$ struct('gui_Name', mfilename, ... 'gui_Singleton', gui_Singleton, ... 'gui_OpeningFcn', @aplikasi_OpeningFcn,... 'gui_OutputFcn', @aplikasi_OutputFcn, ... 'gui_LayoutFcn', [] _ , ... 'gui_Callback', []); if nargin \&\& ischar(varargin $\{1\}$ ) gui_State.gui_Callback str2func(varargin $\{1\})$; end

if

[varargout $\{1$ :nargout $\}$ ] gui_mainfcn(gui_State, else gui_mainfen(gui_State, end

\subsection{Pengertian Metode Delta Modulation}

Salah satu skema yang paling sederhana dalam prediksi lossy adalah Delta Modulation, dimana sampel ini diperkirakan sebagai s (n) dalam hal masa lalu segera direkonstruksi sampel s ( $\mathrm{n}-1)$. Delta modulasi (DM) adalah bentuk terkenal dari predictive coding lossy dimana rumus proses delta modulasinya didefinisikan sebagai:

for $\mathrm{i}=1$ :length(sig)-1

if $\operatorname{xr}(\mathrm{i})<=\operatorname{sig}(\mathrm{i})$ $\operatorname{xr}(i+1)=x r(i)+d e l ;$

else

$\operatorname{xr}(\mathrm{i}+1)=\mathrm{xr}(\mathrm{i})$-del;

end

Delta modulasi (DM) adalah metode konversi A/D yang sederhana dan handal pada sistem yang membutuhkan komunikasi digital secara serial dari sinyal analog. Delta Modulasi terdiri dari komparator pada bagian umpan maju dan integrator sebagai umpan balik untuk membentuk suatu loop kontrol yang sederhana. DM dibatasi oleh frekuensi dan amplitudo analog input yang akan diproses. Dengan DM, suatu input analog didekati melalui fungsi tangga yang bergerak naik turun dengan satu level kuantisasi.Pada setiap level interval sampling $\left(\mathrm{T}_{\mathrm{s}}\right)$. Contoh mengenai hal itu ditunjukkan pada gambar 1 dimana fungsi tangga berhimpit pada gelombang analog yang asli. Karakteristik terpenting untuk fungsi tangga ini adalah jalannya mirip biner. Pada setiap waktu pengambilan sampel, fungsi bergerak naik turun .Sehingga output dari proses modulasi delta dapat ditampilkan sebagai suatu digit digital biner tunggal untuk setiap sampel. Pada dasarnya, aliran bit lebih dihasilkan oleh pendekatan derivatif sinyal analog dari amplitudonya, yaitu A1 dibangkitkan bila fungsi tangga menaik sepanjang interval sedangkan 0 dibangkitkan dengan cara sebaliknya.

Modulasi adalah sebuah proses untuk menumpangkan sebuah data informasi ke sebuah sinyal carier tertentu. Sedangkan demodulasi adalah sebuah proses untuk memisahkan data dengan sinyal pembawanya. Dalam system ini kita menggunakan metode modulasi dan demodulasi BPSK. BPSK (Binary Phase Shift Keying) merupakan salah satu teknik modulasi digital. Nama lain dari BPSK adalah PRK dan Biphase Modulation. BPSK merupakan bentuk yang paling sederhana dari PSK (Phase Shift Keying). BPSK menghasilkan output yang mempunyai 2 perbedaan fase sinyal carrier. 


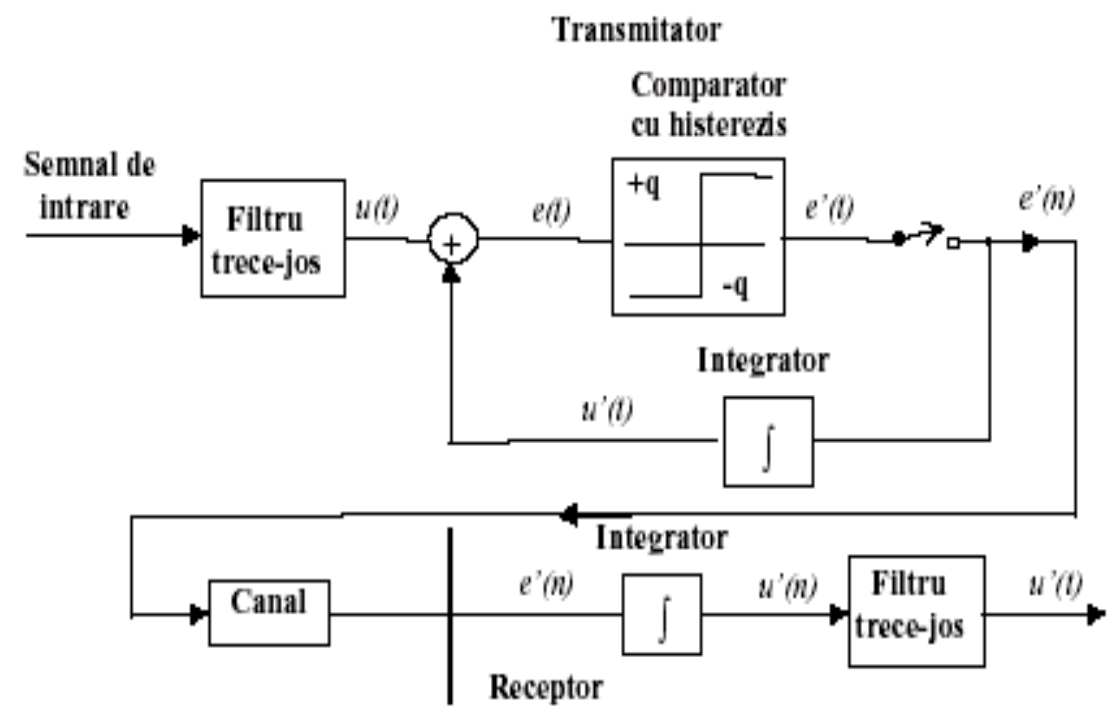

a. Sistem practic MD

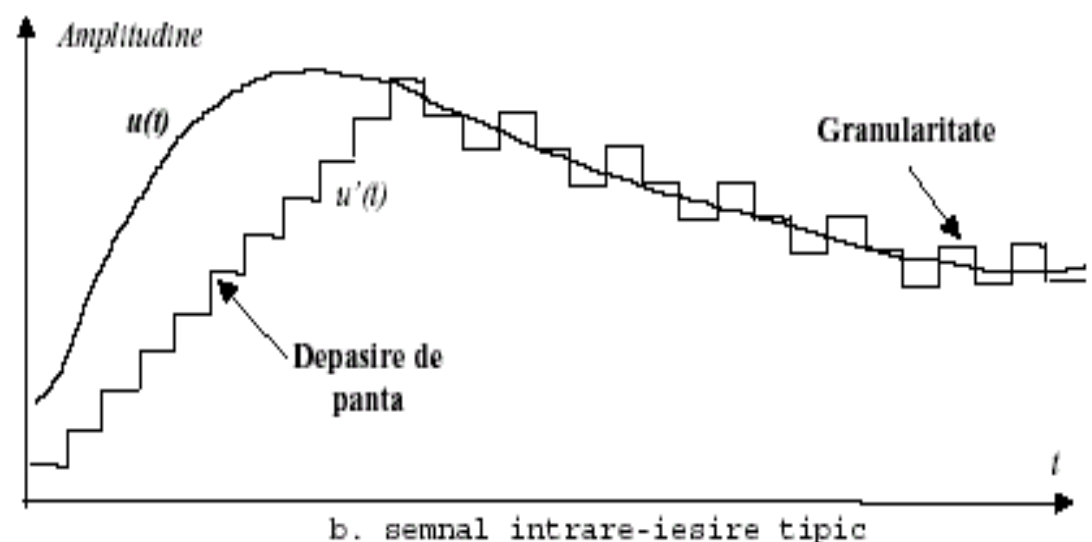

\begin{tabular}{|c|c|c|c|c|c|}
\hline Symbol & Bit & Expression & $\begin{array}{c}\text { Modulation Signal } \\
\text { at } \mathrm{f}_{\mathrm{c}}=1 \mathrm{~Hz}\end{array}$ & $\begin{array}{c}\mathrm{Q} \\
\text { At } \mathrm{f}_{\mathrm{c}}=0\end{array}$ & At $\mathrm{f}_{\mathrm{c}}=0$ \\
\hline S1 & 0 & $\sqrt{\frac{2 E_{1}}{T}} \cos (2 \pi f l+0)$ & & 1 & 0 \\
\hline S2 & 1 & $\sqrt{\frac{2 E_{2}}{T}} \cos (2 \pi f i+\pi)$ & - & -1 & 0 \\
\hline
\end{tabular}

Gambar 2. Tabel modulasi BPSK

Dari kata Binary yang berarti "2", input phase carrier dengan menggeser sebesar 1800 . logika "1" menghasilkan output phase satu dan Sinyal yang termodulasi BPSK di definisikan logika "0" menghasilkan output phase lainnya. mempunyai bentuk :

Sinyal input digital (biner) akan mengubah ()$\theta \pi+=f t A t x 2 \sin )(0<\mathrm{t}<\mathrm{T}$ 
dengan : $E A=T 2$

Pada gambar 3 menunjukkan diagram BPSK pada bidang kompleks dengan konstelasi dari tiap bit. Delta Modulasi Differential pulse-code modulation adalah teknik turunan dari sinyal terkuantisasi. Ketika sinyal perubahan antara periode sampel kecil, firman quantizer panjang dapat dikurangi. With very high oversampling rates, the changes between sample periods are madevery small, thus the quantizer can be reduced to low-bit. Tingkat oversampling sangat tinggi, perubahan antara periode sampel dibuat sangat kecil, sehingga dapat dikurangi quantizer rendah-bit. A 1-bit DPCM encoder dikenal sebagai modulasi delta (DM, delta). Kode DM perbedaan amplitudo sinyal bukannya amplitudo sinyal itusendiri. Nama lain untuk DM adalah modulasi lebar pulsa (PWM). Gambar 4 menunjukkan sebuah delta-modulasi encoder; itu dikenal sebagai integrasi tunggalmodulasi. Sinyal input dibandingkan dengan output terpadu kacang-kacangan dan delta (perbedaan) sinyal diterapkan pada quantizer. The quantizer menghasilkan pulsa positif ketika perbedaan sinyal negatif, dan negatif perbedaan denyut nadi ketika sinyal positif. Perbedaan ini sinyal integrator bergerak selangkah demi selangkah lebih dekat ke nilai sekarang masukan, pelacakan turunan dari sinyal input. Menimbang $1,5 \mathrm{kHz}$ sinyal input sinusoidal, sebagai contoh, dengan amplitudo maksimum 1 dan delta $\mathrm{V}$ untuk menjadi 0,0625, sampling setara dengan 4-bit kuantisasi yaitu $\mathrm{L}=16$.Untuk mencapai kecepatan bit setara dengan 4-bit kuantisasi dengan $4 \mathrm{kHz}$ sampling rate yang oversampling rasio 16 adalah dibutuhkan yaitu $64 \mathrm{kHz} \quad(16 \quad \mathrm{x} \quad 4 \mathrm{kHz})$. Gambar 5, memperlihatkan sebuah simulasi MATLAB pada 32 kali oversampling.

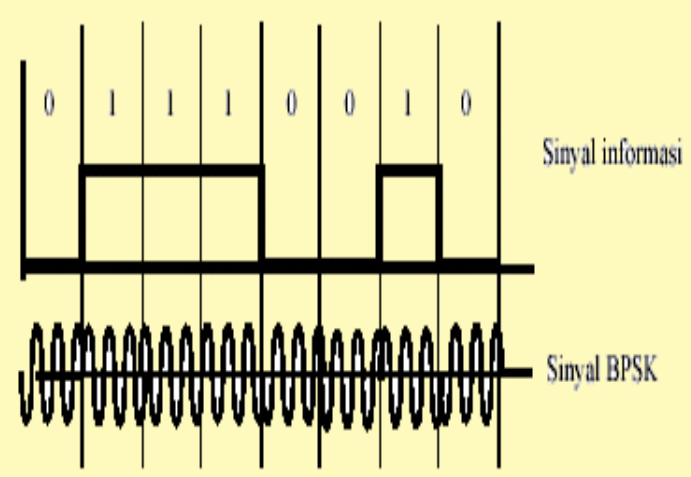

Gambar 3. Sinyal BPSK

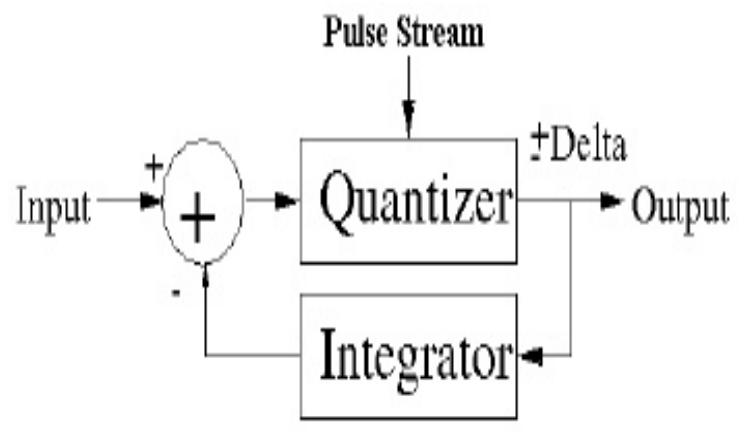

Figure 2: Delta Modulation Encoder

Gambar 4. menunjukkan sebuah deltamodulasi encoder

Seperti yang dijelaskan sebelumnya, adalah penting dalam menyaring oversampling untuk menghindari efek yang tidak diinginkan dan distorsi. Setelah pikiran ini dalam output dari delta modulation (setelah integrator) harus melewati pass filter yang rendah untuk melemahkan sinyal frekuensi tinggi yang tidak diinginkan. Gambar 5 adalah simulasi MATLAB yang menunjukkan efek tidak menggunakan filter seperti di 16 kali oversampling dari sinyal yang digunakan. Seperti melihat sinyal termodulasi hampir tidak melacak sinyal input yang sebenarnya dan sebagai sinyal terpadu dialihkan karena efek aliasing. Distorsi diperkenalkan dan direproduksi di demodulator sinyal tidak akan menyerupai sinyal input asli (ada juga ada cara untuk memulihkan itu). 


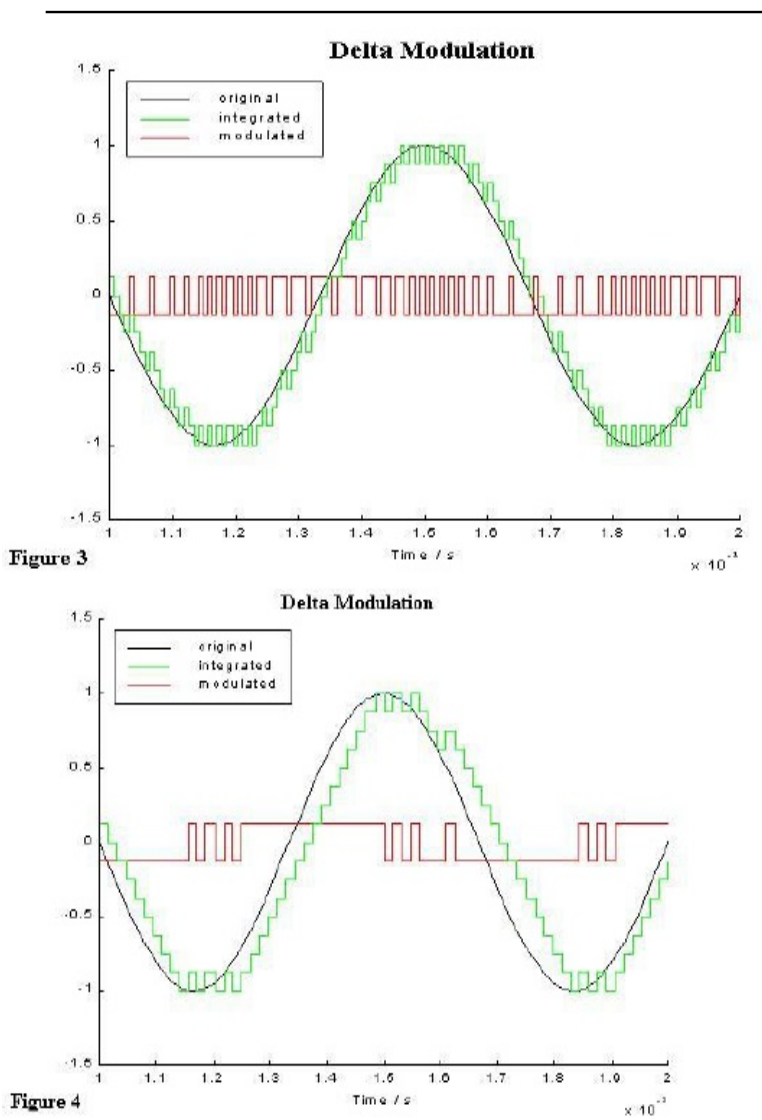

Gambar 5. Gambar simulasi matlab filter delta modulation.

DM (Delta Modulation) adalah versi sederhana dari DPCM yang digunakan sebagai converter analog-ke-digital cepat. Perhatikan bahwa prediksi hanya melibatkan penundaan Linear Predictive Coding (LPC) Teknik. Berdasarkan kompleksitas dalam step size dan ukuran gambar itu. Delta Modulation (DM) Menggunakan step size dan satu fungsi DMSIG (delta modulation sigma).

Beberapa manfaat dari modulasi delta (Delta Modulation ) adalah sebagai berikut :

a. 1 bit dari resolusi, dan karena itu memerlukan bandwidth yang sangat kecil dan perangkat keras sangat sedikit.

b. Tidak ada batas atas atau bawah preset, sehingga Delta modulasi dapat (secara teoritis) digunakan untuk memodulasi sinyal terbatas.

c. Lossy prediktif coding terjadi ketika kesalahan prediksi yang terkuantisasi sebelum coding, jadi ada kesalahan kecil dalam output gambar.

Tujuan dari predictive coding adalah untuk mengambil keuntungan dari redundansi spasial dan pengkodean redundansi dalam gambar. Cara kerja Predictive coding adalah dengan menggunakan nilai pixel sebelumnya untuk memprediksi nilai pixel berikutnya, contohnya : $\mathrm{p}(\mathrm{x}, \mathrm{y})=\mathrm{f}(\mathrm{x}-1, \mathrm{y}) \operatorname{dan} \mathrm{p}(\mathrm{x}, \mathrm{y})=[\mathrm{f}(\mathrm{x}-1, \mathrm{y})$ $+\mathrm{f}(\mathrm{x}, \mathrm{y}-1)]$ / 2. Kemudian selanjutnya menghitung kesalahan prediksi $e(x, y)=f(x$, $y)-p(x, y)$. Kesalahan prediksi akan kurang berkorelasi satu sama lain daripada gambar input, jadi harus mengurangi redundansi spasial.

1.6 Keuntungan Teknik Kompresi Lossy (Lossy Compression)

Berikut ini adalah beberapa keuntungan dari teknik mengkompres gambar menggunakan metode Lossy Compression , antara lain :

a. Keuntungan dari metode lossy atas metode lossless adalah dalam bebeapa kasus metode lossy dapat menghasilkan file kompresi yang lebih kecil dibandingkan dengan metode lossless yang ada, ketika masih memenuhi persyaratan aplikasi.

b. Metode lossy sering digunakan untuk mengkompresi suara, gambar dan video. karena data tersebut dimaksudkan kepada human interpretation dimana pikiran dapat dengan mudah "mengisi bagian-bagian yang kosong" atau melihat kesalahan masa lalu sangat kecil atau inkonsistensi-idealnya lossy adalah kompresi transparan, yg dapat diverifikasi dengan tes ABX. Sedangkan lossless digunakan untuk mengkompresi data untuk diterima ditujuan dalam kondisi asli seperti dokumen teks.

c. Lossy akan mengalami generation loss pada data sedangkan pada lossless tidak terjadi karena data yang hasil dekompresi sama dengan data asli.

\subsection{Pengertian Modulasi Delta}

Modulasi Delta adalah suatu teknik konversi sinyal analog to digital dan digital to analog yang digunakan untuk transmisi informasi suara. Modulasi Delta merupakan sebuah teknik modulasi sinyal input analog didekati melalui fungsi tangga yang bergerak naik turun dengan satu level kuantisasi $(\delta)$ pada setiap interval sampling. Bentuk fungsi tangga berhimpit mendekati bentuk gelombang sinyal informasi. Modulasi Delta pada dasarnya tersusun atas beberapa blok 
rangkaian, yaitu differential amplifier, komparator, clock and pulse generator, integrator dan low pass filter.

Semua rangkaian tersebut tersusun sedemikian rupa sehingga dapat menghasilkan modulasi delta dengan baik. Pada setiap pengambilan sampel, fungsi bergerak naik turun sebesar $\delta$, sehingga output dari modulasi delta dapat ditampilkan sebagai digit biner untuk setiap sampelnya. Berdasarkan hasil Pengujian dan pengamatan rancangan Modulasi Delta, diketahui bawha proses modulasi terjadi pada rangkaian clock and pulse generator menghasilkan gelombang kotak yang mengikuti bentuk sinusoidal. Output dari modulasi delta ini adalah runtunan bilangan biner yang membentuk fungsi tangga.

Delta modulasi sangat sederhana, dan memberikan kinerja acceptible di banyak aplikasi, tapi jelas terbatas. Salah satu cara untuk mencoba untuk meningkatkan kinerja adalah dengan menggunakan adaptif DM, ukuran langkah ini tidak diperlukan untuk menjadi konstan. (Sistem komunikasi suara pada pesawat ulang-alik AS membuat penggunaan teknik ini) lain. adalah dengan menggunakan delta PCM, setiap langkah yang diinginkan ukuran dikodekan sebagai sinyal PCM (sedikit banyak), dan ditransmisikan ke penerima sebagai codeword. Differential PCM adalah serupa, tetapi mengkodekan perbedaan antara sampel dan yang diperkirakan nilai ini selanjutnya dapat mengurangi jumlah bit diperlukan untuk transmisi.

1.8 Nilai MSE dan PSNR

Kualitas citra dalam hasil proses kompresi sangat penting dan harus bagus (fidelity). Informasi yang hilang akibat kompresi seharusnya seminimal mungkin sehingga kualitas hasil kompresi bagus. Tetapi biasanya kualitas kompresi bagus bila proses kompresi menghasilkan pengurangan memori yang tidak begitu besar, demikian sebaliknya.

Kompresi citra terdapat standar pengukuran error (galat) kompresi yaitu:

a. MSE (Mean Square Error), yaitu sigma dari jumlah error antara citra hasil kompresi dan citra asli.

b. PSNR (Peak Signal to Noise Ratio), yaitu untuk mengukur kualitas hasil kompresi.

\section{PSNR $=20 x \log 10\left(\frac{\partial}{2 \times 42}\right)$}

Nilai b merupakan nilai maksimum dari piksel citra yang digunakan. Nilai $b$ pada Tugas Akhir ini adalah 255. Nilai MSE yang semakin rendah akan semakin baik, sedangkan semakin besar nilai PSNR, semakin bagus kualitas kompresi. PSNR memiliki satuan decibel (dB). Parameter-parameter citra yang penting dalam proses kompresi diantaranya adalah sebagai berikut :

a. Resolusi

Resolusi citra menyatakan ukuran panjang kali lebar dari sebuah citra. Resolusi citra biasanya dinyatakan dalam satuan pikselpiksel. Semakin tinggi resolusi sebuah citra, semakin baik kualitas citra tersebut. Namun, tingginya resolusi menyebabkan semakin banyaknya jumlah bit yang diperlukan untuk menyimpan dan mentransmisikan data citra tersebut.

b. Kedalaman Bit

Kedalaman bit menyatakan jumlah bit yang diperlukan untuk merepresentasikan tiap piksel citra pada sebuah frame. Kedalaman bit biasanya dinyatakan dalam satuan bit / piksel. Semakin banyak jumlah bit yang digunakan untuk merepresentasikan sebuah citra, maka semakin baik kualitas citra tersebut

\section{c. Konsep Redundansi}

Redundansi merupakan suatu keadaan dimana representasi suatu elemen data tidak bernilai signifikan dalam merepresentasikan keseluruhan data. Keadaan ini menyebabkan data keseluruhan dapat direpresentasikan secara lebih kompak dengan cara menghilangkan representasi dari sebuah elemen data yang redundan. Redundansi yang terdapat pada citra statis adalah redundansi spasial.

\section{METODE PENELITIAN}

Proses kerja sistem kompresi citra yaitu dengan memasukkan data berupa gambar atau citra yang telah ditentukan formatnya diantaranya jpg, bmp, tiff dan png. Semua format file gambar tersebut akan dilakukan kompresi dengan menggunakan Algoritma Delta Modulation.

Algoritma dari program kompresi citra dengan metode delta modulation seperti yang terlihat pada gambar 6 adalah : 
a. Sebuah gambar baik gambar grayscale, black and white dan true color. Diproses didalam fungsi dmsig.

b. Panjang dari gambar tersebut di umpamakan sebagai I, lalu $(a, b)=I$.

c. Menentukan ukuran dari gambar tersebut dengan rumus $[a, b]=\operatorname{size}(\mathrm{I})$; setelah panjang dan lebar gambar diketahui dan diatur sesuai rumus delta modulation.

d. Gambar tadi masuk ke proses penghitungan luas citra dan penentuan nilai maksimal resolusi gambar.Proses ini memakai rumus $1=\mathrm{a} * \mathrm{~b}$;

$$
\begin{aligned}
& \mathrm{Y}=[0] ; \\
& \mathrm{Xr}=0 ;
\end{aligned}
$$

e. Lalu citra atau gambar diubah ke suatu bentuk baris sinyal ,panjang lurus sesuai dengan panjang citra. sig=reshape $(\mathrm{I}, 1,1)$;

f. Gambar setelah diubah menjadi baris sinyal panjang lurus ,lalu masuk ke proses kompresi delta modulation .Prosesnya adalah dgn rumus :

for $\mathrm{i}=1$ :length(sig)-1

$$
\begin{aligned}
& \text { if } \operatorname{xr}(i)<=\operatorname{sig}(i) \\
& \operatorname{xr}(i+1)=\operatorname{xr}(i)+d e l ; \\
& \text { else } \\
& \operatorname{xr}(i+1)=x r(i)-d e l ; \\
& \text { end }
\end{aligned}
$$

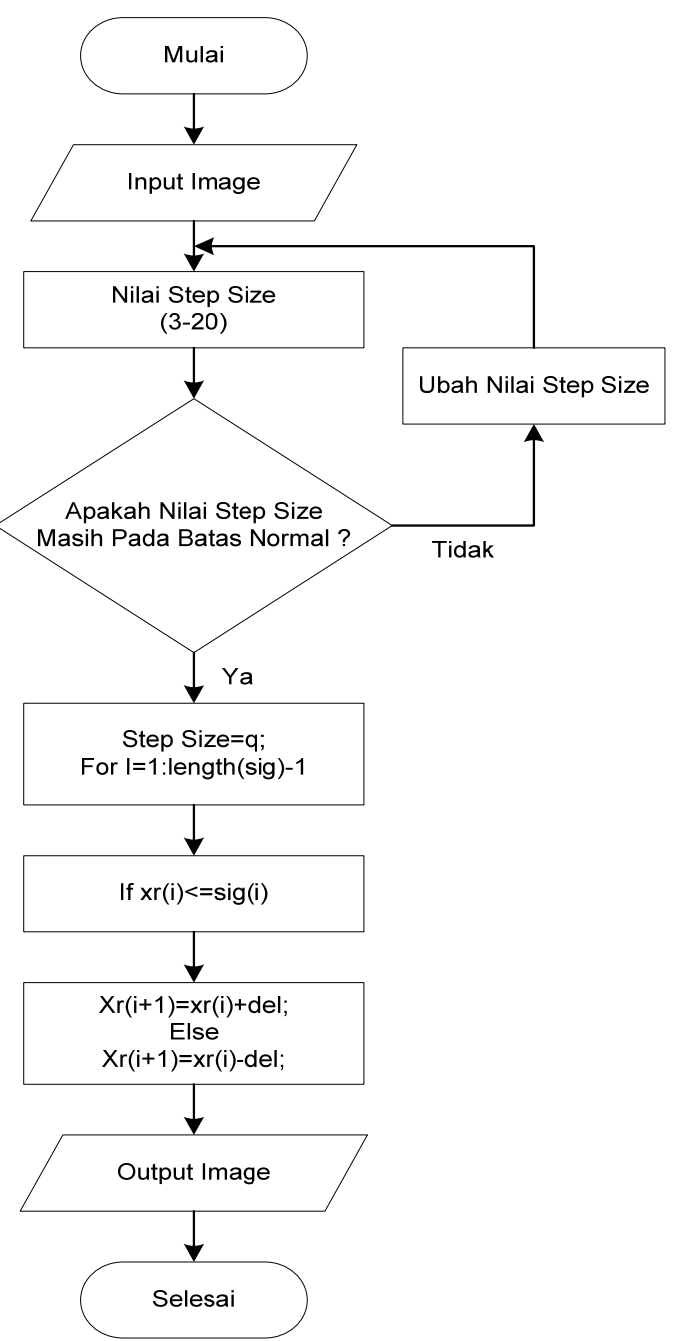

g. Setelah diproses dengan rumus delta modulation maka gambar yang berupa sinyal panjang tadi direkonstruksi kembali menjadi sebuah citra yang telah mengalami proses kompresi delta modulation.Merekonstruksi citra dari sebuah sinyal panjang lurus tadi dengan script : $\mathrm{hf}=$ =reshape $(\mathrm{xr}, \mathrm{a}, \mathrm{b})$;

h. Lalu gambar hasil kompresi dengan delta modulation siap di tampilkan di axes.

Gambar 6. Flowchart Algoritma Delta Modulation.

\section{HASIL DAN ANALISA}

Hasil pengujian program disampaikan dalam tabel 1 berikut ini:

Tabel 1. Hasil Pengujian Program.

\begin{tabular}{cccc}
$\begin{array}{c}\text { Nama } \\
\text { File \& } \\
\text { Format }\end{array}$ & $\begin{array}{c}\text { Ukuran } \\
\text { File } \\
\text { Masukan }\end{array}$ & $\begin{array}{c}\text { Ukuran } \\
\text { File } \\
\text { Keluaran } \\
\text { Format } \\
\text { JPG }\end{array}$ & $\begin{array}{c}\text { Ukuran } \\
\text { File } \\
\text { Keluaran } \\
\text { Format } \\
\text { Asli }\end{array}$ \\
\hline $\begin{array}{c}\text { Barbara. } \\
\text { Bmp }\end{array}$ & 170 & 12.883 & 170 \\
$\begin{array}{c}\text { Goldhill } \\
\text { Bmp }\end{array}$ & 216 & 14.416 & 216 \\
$\begin{array}{c}\text { Lena. } \\
\text { Bmp }\end{array}$ & 177 & 10.999 & 177 \\
$\begin{array}{c}\text { Mountai } \\
\text { n. Bmp } \\
\text { Sails. }\end{array}$ & 130 & 16.047 & 130 \\
Bmp & 125 & 10.954 & 125 \\
Didik & 15.0 & 10.1 & 10.1 \\
.jpg & & & \\
\hline
\end{tabular}




\begin{tabular}{|c|c|c|c|}
\hline $\begin{array}{c}\text { Nama } \\
\text { File \& } \\
\text { Format }\end{array}$ & $\begin{array}{c}\text { Ukuran } \\
\text { File } \\
\text { Masukan }\end{array}$ & $\begin{array}{l}\text { Ukuran } \\
\text { File } \\
\text { Keluaran } \\
\text { Format } \\
\text { JPG }\end{array}$ & $\begin{array}{l}\text { Ukuran } \\
\text { File } \\
\text { Keluaran } \\
\text { Format } \\
\text { Asli }\end{array}$ \\
\hline $\begin{array}{l}\text { Deltaim } \\
\text { age. Jpg }\end{array}$ & 14.4 & 7.723 & 7.723 \\
\hline Di .jpg & 42.4 & 11.547 & 11.547 \\
\hline $\begin{array}{l}\text { Merapi } \\
\text {.jpg }\end{array}$ & 23.4 & 7.635 & 7.635 \\
\hline $\begin{array}{c}\text { Merapi2 } \\
\text {.jpg }\end{array}$ & 19.2 & 9.017 & 9.017 \\
\hline $\begin{array}{c}\text { peppers } \\
\text {.Png }\end{array}$ & 165 & 12.845 & 102.69 \\
\hline $\begin{array}{l}\text { Girl } \\
\text {.Png }\end{array}$ & 134 & 10.482 & 93.17 \\
\hline $\begin{array}{l}\text { tulips } \\
\text {.Png }\end{array}$ & 111 & 12.096 & 77.803 \\
\hline $\begin{array}{l}\text { Watch } \\
\text {.Png }\end{array}$ & 89.9 & 10.857 & 79.669 \\
\hline $\begin{array}{l}\text { Frymire } \\
\text {.Png }\end{array}$ & 128 & 22.388 & 108.45 \\
\hline $\begin{array}{l}\text { Camera } \\
\text { man .tif }\end{array}$ & 63.7 & 6.863 & 50.062 \\
\hline $\begin{array}{c}2.1 .05 \\
\text { tif }\end{array}$ & 260 & 19.565 & 230.91 \\
\hline $\begin{array}{l}\text { Preside } \\
\text { n .tif }\end{array}$ & 61.3 & 6.399 & 147.30 \\
\hline $\begin{array}{l}2.1 .03 \\
. \text { tif } \\
\end{array}$ & 216 & 9.674 & 249.57 \\
\hline
\end{tabular}

\section{KESIMPULAN}

Beberapa hal yang dapat disimpulkan dalam penelitian ini antara lain sebagai berikut:

a. Kompresi citra dengan menggunakan metode Delta Modulation, akan mengubah ukuran gambar baik gambar yang berformat jpg, bitmap, png dan tif. Gambar dapat di atur tingkat kejelasan yang diinginkan dengan cara mengganti step size delta (standarnya memakai 3 sampai 10) semakin besar skala step sizenya maka kualitas gambar makin buruk. Karena panjang proses deltamodulasinya juga makin lama.

b. Analisa ukuran citra, setiap citra yang terkompresi memiliki ukuran sendirisendiri. Setiap format file memiliki rasio kompresi yang berbeda-beda .Terutama dalam penyimpanan hasil gambar yang sudah dikompresi, masing-masing format gambar memiliki rasio kompresi yang berbeda-
beda.Rasio kompresi yang didapatkan adalah banyaknya bagian yang masih ada dari citra original setelah mengalami proses kompresi ( rata-rata menghasilkan rasio kompresi yang besar )Karena memakai nilai step size yang kecil,jadi hasil yang diperoleh masih ada kemiripan dengan citra aslinya walaupun kualitas kurang baik.

c. Hasil rata-rata kompresi gambar yang di dapatkan dari masing-masing format gambar berbeda-beda hasilnya .Gambar dengan format jpg memiliki rasio kompresi paling tinggi diantara format-format gambar lain.

d. Pengukuran kualitas gambar dan kualitas kompresi diukur berdasarkan nilai MSE dan PSNR.Jika nilai MSE makin rendah maka makin baik kualitas gambar hasil kompresi dan nilai PSNR makin tinggi maka semakin bagus kualitas kompresi dengan metode tersebut.pada pengujian program kompresi menggunakan metode delta modulation didapatkan hasil PSNR yang rendah dan nilai MSE nya tinggi. Hasil ini menunjukkan bahwa kualitas gambar yang dihasilkan buruk, karena nilai MSE tinggi. Hasil pengukuran nilai MSE dan PSNR. Dari hasil yang didapat, maka disimpulkan bahwa gambar dengan format jpg memiliki kualitas gambar yang paling baik karena nilai MSE yang rendah.Untuk kualitas kompresi terbaik juga terdapat pada format jpg yang memiliki nilai PSNR lebih tinggi dari format lain.

e. Metode Delta Modulation menghasilkan gambar output dengan kualitas yang baik, tetapi dengan ukuran yang lebih kecil dari gambar asli dan baik digunakan untuk mengkompres file gambar yang menghasilkan gambar output berformat Jpg. Kekurangan dari metode ini hanya baik jika mengkompresi file gambar yang menghasilkan output format jpg.

f. Kelebihan metode ini adalah bisa mengkompresi gambar grayscale, 
black and white dan true color. Jadi sangat aplikatif dengan bermacam macam file gambar yang ada saat ini. Ukuran hasil kompresi menggunakan metode Delta Modulation relatif kecil, tapi kualitas gambar juga masih bagus .

\section{DAFTAR PUSTAKA}

Amir, Said. 2004. Comparative Analysis of Arithmetic Coding Computational Complexity. HP Laboratories Palo Alto California USA : Imaging Systems Laboratory.

Angga, 2009, Kompresi Citra. http://angga212.wordpress.com.

Diakses pada tanggal 25 Januari 2012. pukul 16.00 WIB.

Blelloch, Guy E. 2001. Introduction to Data Compression, Computer Science Department, Carnegie Mellon University Diakses 27 Maret 2005 6:25:12 AM.

Departmen Teknik Elektro, Modul Praktikum Pengolahan Citra dan Pengenalan Pola ,Institut Teknologi Bandung.

Engleza, Mihaela.1993.Predictive Coding Delta Modulation \& DPCM .U.S.A. : Piscataway, NJ: IEEE Press, 1993, pp.325-350.)
Etter, Dolores. 2003. Pengantar Matlab 6. PT.Indeks Kelompok Gramedia. Jakarta.

Fauzi . 2006 .Skripsi Kompresi Citra Dengan Arithmetic Coding.Universitas Sumatera Utara .

Gonzalez, Raffel .2000. Multimedia System chapter 7 : Data Compression .

IEEE Trans. Communications, pp. 660-666, June 1975.

Hanselman Duane\&Littlefield Bruce. 1997. The Student of MATLAB:version 5,. Prentice Hall,Inc.New Jersey.

H.R. Schindler. "Delta Modulation," IEEE Spectrum 7,69 ( October 1970 ).

H . Kobayashi ," Adaptive Data Compression System," IBM Tech, Disclosure Bull . 14, 1305 ( 1971 ).

Knight, Andrew.1999. Basics Of Matlab And Beyond . U.S.A. : The MathWorks, Inc. 24 Prime Park Way.

Nelson, Mark. 1991. The Data Compression Book. U.S.A. : M\&T Books, , hal 3247. 